\title{
Postglacial Faults in Fennoscandia: Targets for scientific drilling
}

\author{
ILMO T. KUKKONEN ${ }^{1}$, ODLEIV OLESEN ${ }^{2}$, MARIA V.S. ASK ${ }^{3}$ and the PFDP WORKING GROUP ${ }^{4}$
}

Kukkonen, I.T., Olesen, O., Ask, M.V.S. \& the PFDP Working Group, 2010: Postglacial Faults in Fennoscandia: Targets for scientific drilling. GFF, Vol. 132 (Pt. 1, March), pp. 71-81. Stockholm. ISSN 1103-5897.

\begin{abstract}
During the last stages of the Weichselian glaciation (ca. 9,000-15,000 years B.P.), reduced ice loads and glacially affected stress fields resulted in active faulting in Fennoscandia with fault scarps up to $160 \mathrm{~km}$ long and up to $30 \mathrm{~m}$ high. These postglacial (PG) faults are usually SE dipping, SW-NE oriented thrusts, and represent reactivated, pre-existing crustal discontinuities. Postglacial faulting indicates that the glacio-isostatic compensation is not only a gradual viscoelastic phenomenon, but also includes unexpected violent earthquakes, suggestively larger than other known earthquakes in stable continental regions. We explore here possibilities and benefits for investigating, via scientific drilling, the characteristics of postglacial faults in northern Fennoscandia, including their structure and rock properties, present and past seismic activity and state of stress, as well as hydrogeology and associated deep biosphere. The research is anticipated to advance science in neotectonics, hydrogeology and deep biosphere studies, and provide important information for nuclear waste disposal, petroleum exploration on the Norwegian continental shelf and studies of mineral resources in PG fault areas.
\end{abstract}

Keywords: Postglacial faults, Fennoscandian Shield, drilling, glaciation, tectonics, seismicity, earthquakes, groundwater flow, groundwater chemistry, deep biosphere.

\author{
${ }^{1}$ Geological Survey of Finland, Espoo, P.O. Box 96, FI-02151 Espoo, Finland, ilmo.kukkonen@gtk.fi \\ ${ }^{2}$ Geological Survey of Norway, NO-7491 Trondheim, Norway \\ ${ }^{3}$ Luleå University of Technology, SE-971 87 Luleå, Sweden \\ ${ }^{4}$ see appendix \\ Manuscript received 2 July 2009. Revised manuscript accepted 9 February 2010.
}

\section{Introduction}

The reduction of ice loads resulted in rapid uplift in Fennoscandia during the last stages of the Weichselian glaciation $(\sim 9,000-15,000$ years B.P.). The contemporary in situ stress field, which was influenced by deglaciation, resulted in active faulting of the bedrock in northern Fennoscandia (Lagerbäck 1979, 1990; Olesen 1988; Johnston 1989; Muir-Wood 1989, 1993, 2000; Olesen et al. 1992, 2004; Kuivamäki et al. 1998; Wu et al. 1999; Dehls et al. 2000a; Ojala et al. 2004; Lund 2005; Turpeinen et al. 2008; Lagerbäck \& Sundh 2008; Lund et al. 2009). These faults are called postglacial or late-glacial faults depending on whether they formed in extramarginal or subglacial conditions. We use here the term postglacial $(P G)$ faulting as a generic term for these faults. The exact age of the PG faults depends on the fault location and the withdrawal time of the Weichselian ice sheet.

Impressive PG faulting is known in Fennoscandia in at least 14 localities across northern Finland, Sweden and Norway (Kuivamäki et al. 1998; Olesen et al. 2004; Munier \& Fenton 2004; Lagerbäck \& Sundh 2008; Figs. 1 and 2). The large postglacial faults in northern Fennoscandia are about 2-160 km long, with a vertical displacement of up to $30 \mathrm{~m}$ (e.g., Olesen et al. 2004; Lagerbäck \& Sundh 2008). In addition, minor faults observed as offsets of less than $1 \mathrm{~m}$ of glacially polished bedrock surfaces, exist in southern Finland (Kuivamäki et al. 1998).
Further, disturbed sedimentary structures, submarine slides and slumps, and debris-flow structures in the Gulf of Bothnia have been interpreted as indications of postglacial palaeoseismicity (Kotilainen \& Hutri 2004; Hutri \& Kotilainen 2007). Structures interpreted as indicating postglacial seismic activity occur also in Russian Karelia, in the Lake Onega and Lake Ladoga areas (Lukashov 1995), although the available evidence has not been compelling (Kuivamäki et al. 1998).

The spectacular surface expressions of PG seismic activity in Fennoscandia are unique on Earth, even for other recently deglaciated regions. For instance, in northern America the postglacial faulting is typically represented by much smaller offsets and lengths (Adams 1989; Munier \& Fenton, 2004).

The large PG faults in northern Fennoscandia generally strike SW-NE and they are interpreted to be thrust faults. If these PG faults were formed in single seismic events, their formation would have required the occurrence of earthquakes with magnitudes up to $\mathrm{M}_{\mathrm{w}} \approx 7-8$ (e.g. Muir-Wood 1989; Arvidsson 1996; Bungum \& Lindholm 1997; Olesen et al. 2004). Hence, their presence indicates a much stronger seismicity than the present-day intraplate seismicity of stable continental regions that are generally characterized by smaller earthquakes $\left(M_{w} \leq 4\right)$ (Ahjos \& Uski 1992; Bungum \& Lindholm 1997). 


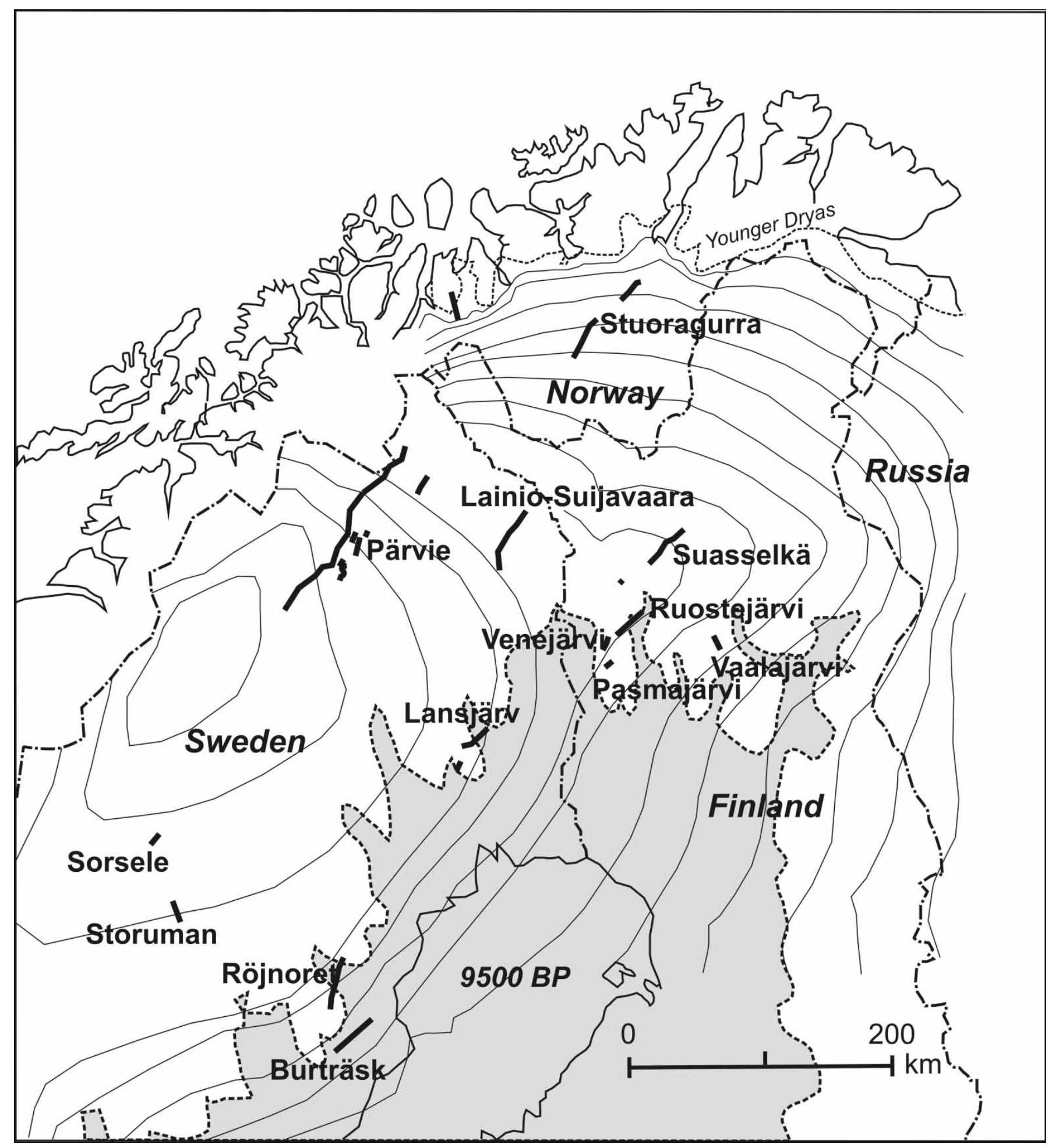

Fig. 1. Location of PG faults in northern Fennoscandia (thick lines), and successive ice-marginal lines between ca. 10,000 and 9,000 years B.P. (thin lines). The grey area shows the highest shoreline of the Baltic. Figure based on Sollid et al. (1973), Kujansuu (1992), Lundqvist (1994), Kuivamäki et al. (1998) and Lagerbäck and Sundh (2008).

The PG faults occur as sharp structures in the glacially formed landscape, discordant to glacial deposits and structures (Figs. 3 and 4). Available literature mostly suggests that postglacial faults represent reactivation of pre-existing structures, with a long history that may extend back to the Precambrian (e.g. Olesen et al. 1992; Kuivamäki et al. 1998; Dehls et al. 2000a; Munier \&
Fenton 2004). However, the details of reactivation (mechanisms, timing, etc.) and why these particular structures were activated, is not fully understood. Opinions on the driving mechanisms differ from dominating rebound mechanisms on one side (e.g. Lagerbäck 1979; Muir Wood 1989, 2000) to a mainly ridge push effect on the other side (e.g. Olesen 1988; Bungum \& 


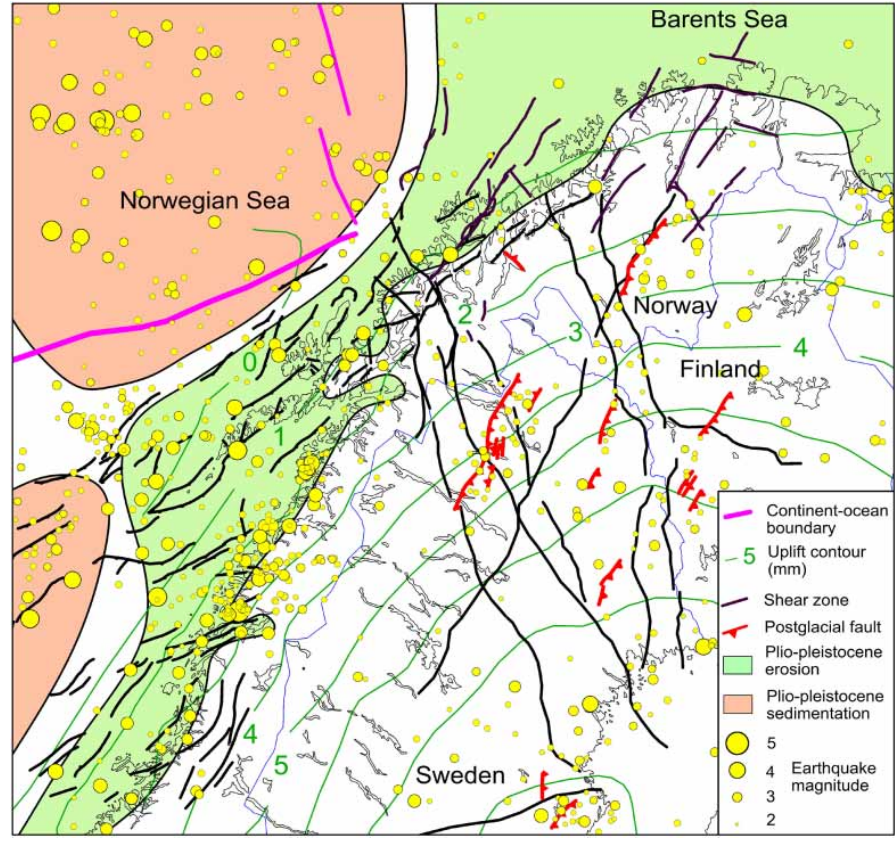

Fig. 2. Earthquakes, postglacial faults, present day uplift and areas of interpreted Plio-Pleistocene deposition and erosion along the Norwegian continental margin (modified from Riis 1996; Byrkjeland et al. 2000; Vestøl 2006; Bungum et al. in press; Olesen et al. in press). The areas of Plio-Pleistocene sedimentation and erosion are coinciding with present-day seismicity indicating that recent loading/unloading is causing flexuring and faulting in the lithosphere.

Lindholm 1997). In addition, other effects such as offshore sedimentary loading (Byrkjeland et al. 2000), topography loading (Pascal \& Cloetingh 2009) and coastal and mainland unloading due to erosion may also contribute to fault activity (Bungum et al. in press; Olesen et al. in press).

Postglacial faulting is a rapid deformation response related to the early glacio-isostatic compensation of the lithosphere after deglaciation. It indicates that the postglacial uplift is not only a gradual phenomenon but may, in interaction with plate tectonic stresses or other tectonic forces, locally trigger earthquakes of high magnitude. The Lapland postglacial fault province is located landward to the bending spreading ridge in the Norwegian-Greenland Sea. Moreover, other important features include the more than $3 \mathrm{~km}$ thick wedge of Plio-Pleistocene sediments along the Barents Sea margin (Riis et al. 1996) and the more than one kilometer deep Pleistocene erosion on the Lofoten-Barents Sea shelf (Cavanagh et al. 2006; Fig. 2). All these three features generate stress variations in the bedrock and may contribute to the anomalous seismicity. The late PliocenePleistocene Bjørnøya Fan is, for instance, $400 \mathrm{~km}$ wide and up to $3.5 \mathrm{~km}$ thick and causes a seismic activity that is higher than anywhere in Fennoscandia (Byrkjeland et al. 2000), even though it is located in oceanic crust which is normally aseismic.

Understanding postglacial faulting has a high societal relevance in countries preparing for final disposal of spent nuclear fuel in bedrock and attempting to predict the future behavior of bedrock during forthcoming glaciations. An improved understanding of the stress distribution at depth may also improve our understanding of the Neogene erosion and deposition along the North-Atlantic and Arctic continental margins and consequently contribute to an improved assessment of the petroleum potential in the region.
We have recently suggested using scientific drilling to investigate the postglacial faults and a proposal, 'Postglacial Fault Drilling Project' (PFDP), was recently submitted to the International Continental Scientific Drilling Program (ICDP) (Kukkonen et al. 2009a). We aim at using scientific drilling to investigate the tectonic and structural properties of postglacial faults, their hydrogeology, as well as the presence and characteristics of their deep biosphere. This research is expected to promote scientific advancement in neotectonics and provide information useful for the safety assessment of nuclear waste repositories and prospecting for mineral resources in PG fault areas.

At present, extensive background information can support scientific drilling investigations of PG faulting in Fennoscandia. Many PG faults in Fennoscandia have been studied with structural/tectonic investigations, ground geophysical surveys, reflection seismic studies, excavations, and a few with shallow drill holes $(<500 \mathrm{~m})$ (Olesen et al. 1992; Roberts et al. 1997; Kuivamäki et al. 1998; Bäckblom \& Stanfors 1998; Olesen et al. 2004; Lagerbäck \& Sundh 2008; Juhlin et al. 2009; Kukkonen et al. 2009b). However, systematic in-situ information on PG faults at depth is still lacking.

In this paper, we discuss the postglacial faults in Fennoscandia and survey possibilities for using drilling to obtain deeper insights into these structures.

\section{Geoscientific investigations of PG faulting -}

\section{state of the art}

Several studies have been devoted to investigation of PG faults. We summarize below what is known about the development, structure, depth extent, mineral alteration, seismicity, stress state, hydrogeology and deep biosphere of PG faults in Fennoscandia, and address some open questions related to them.

\section{History of $P G$ faults}

PG faults are generally located in old zones of weakness which originated much earlier in the geological history, even in the Precambrian. Therefore it is very likely that they have activated many times in different tectonic series of events, but more detailed information is generally lacking. Whether the PG faults would have repeatedly activated at the end of each glaciation is another question. According to Lagerbäck \& Sundh (2008), who based their arguments mainly on the relatively small erosion of the Weichselian glaciation, the sort of dramatic faulting which generated the great PG faults in northern Sweden very probably did not occur in glaciations earlier than the Weichselian. This interpretation inherently assumes that the ice sheets of previous glaciations have been identical with the latest glaciation in respect of their spatial distribution, extent and duration of ice load. These factors, however, have varied between the Early/Middle Weichselian and Late Weichselian ice sheets (Svendsen et al. 2004).

Quantitative age dating of the PG faults is possible in cases where datable sediments with controlled stratigraphy (e.g. till, varved clays or littoral sediments) are favorably located at the fault scarp (e.g. Lagerbäck \& Sundh, 2008). Where carbonaceous sediments are present, traditional radiocarbon-dating has been applied, mostly to provide minimum ages of PG faulting (or ice-free conditions) from peat deposits at the fault scarp or wood buried under landslides (Sutinen 2005; Lagerbäck \& 


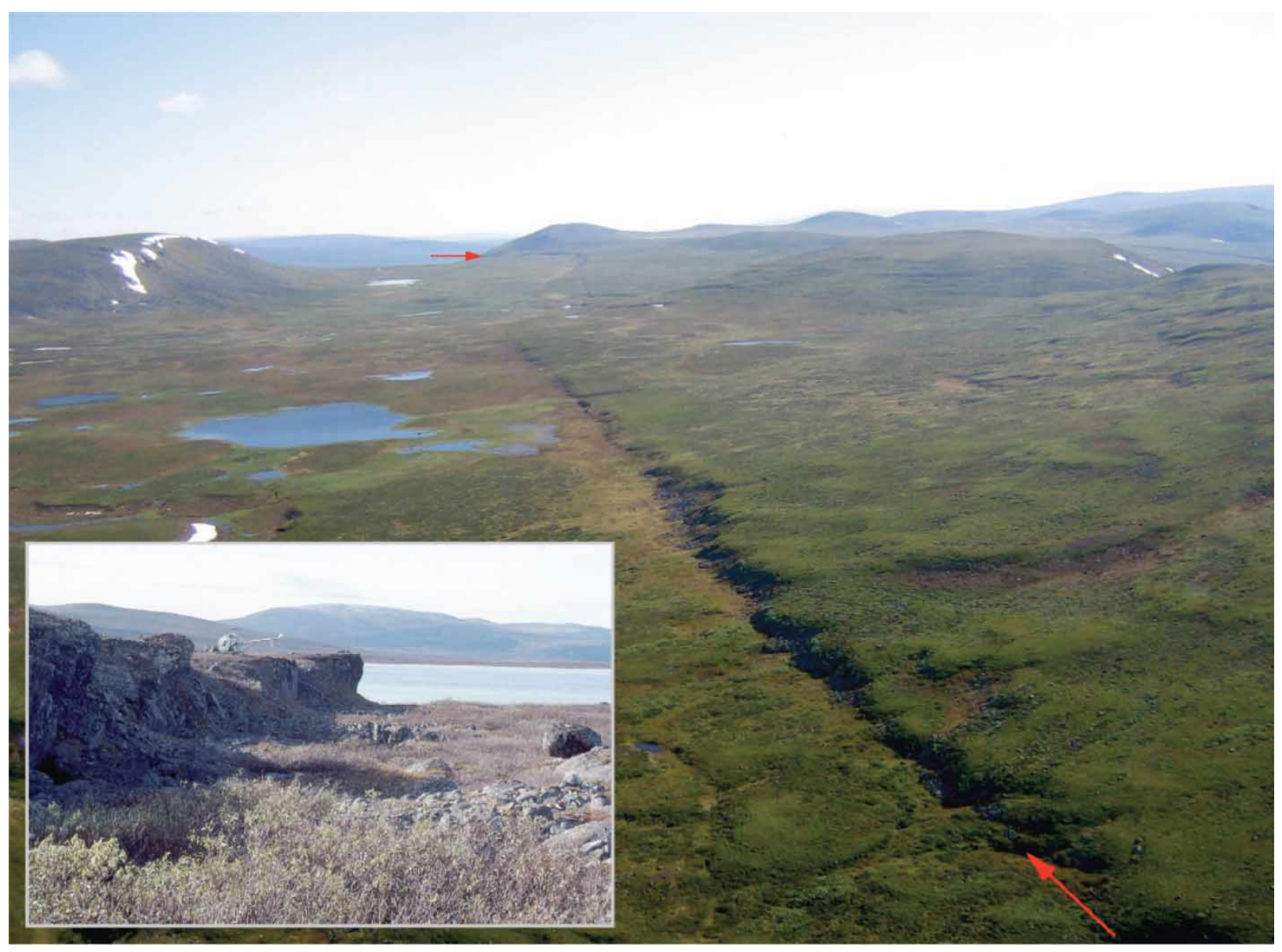

Fig. 3. Helicopter view of the southwestern part of the Pärvie PG fault (see Fig. 1 for location). The red arrows show the trace of the fault scarp. The insert shows the fault scarp from the ground surface, about $85 \mathrm{~km}$ to the northeast of the location of the large photo, including a helicopter for scale. Photo courtesies: Björn Lund, Uppsala University, Sweden (large photo); and Roger Lagerbäck, Geological Survey of Sweden (insert photo).

Sundh 2008). Also thermoluminence (TL), electron-spin resonance (ESR) and optically-stimulated light (OSL) methods have been applied (see Munier \& Fenton 2004 for a summary).
Dating of the fault gouge itself is much more difficult due to the low temperatures and pressures prevailing in the uppermost bedrock which does not necessarily reset the clocks.

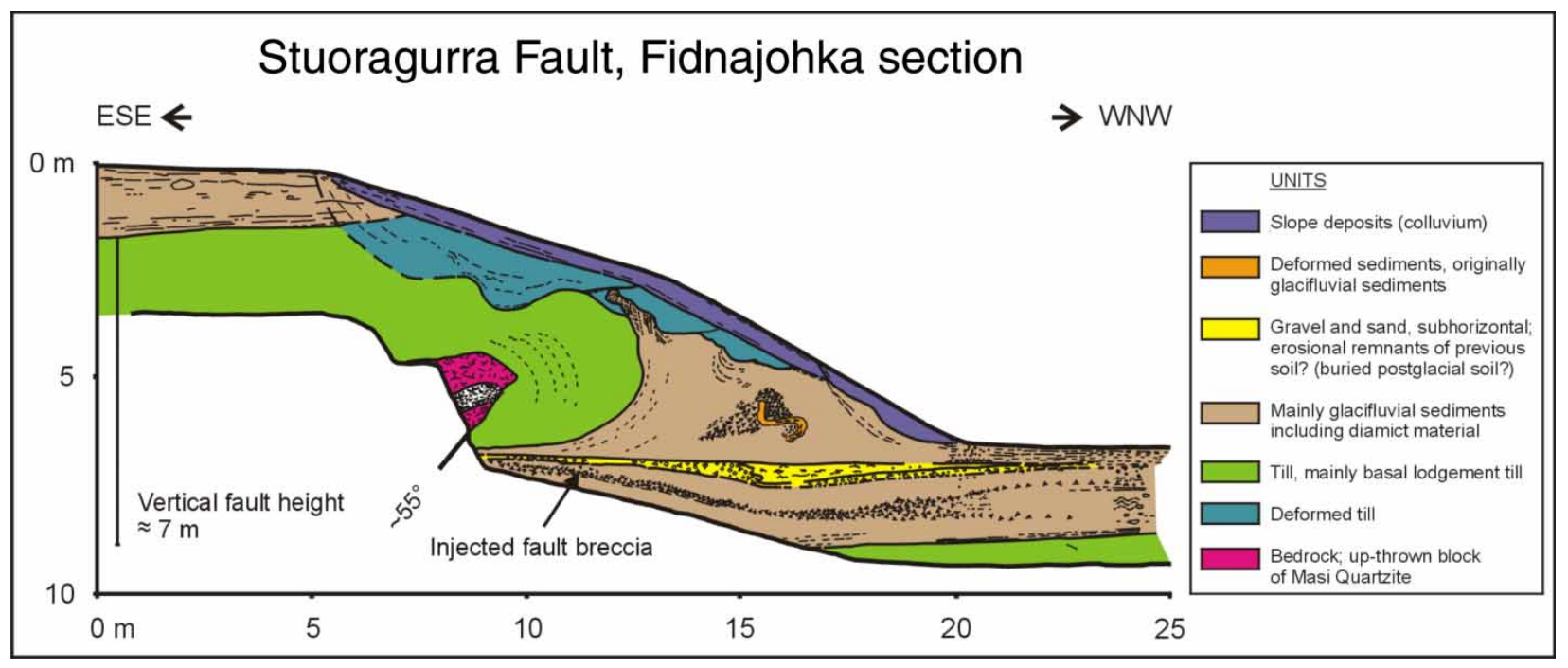

Fig. 4. Folded Quaternary sequence consisting of basal till and glaciofluvial sediments above and in front of the up-thrown hangingwall block of the Stuoragurra Fault. Note the fault breccia that has been injected into the glaciofluvial sediments most likely as a mixture of rock fragments and high-pressure groundwater (Modified from Dehls et al. 2000a). 
The problem is further complicated by the long evolution of the fracture systems in PG faults. It is very likely that useful information can only be compiled from comprehensive geological investigations of the fault evolution with relative and absolute age datings of the fracture fillings (cf. Tullborg et al. 2001 for a summary of age dating methods of fracturing and bedrock movements). It is not very probable that any significant new fracture fillings would have precipitated in PG faults at near-surface depths from the low temperature fluids in the Weichselian and Holocene, but the situation is different at depths of several kilometres. Anyway, one can expect that radiometric and stable isotope techniques would provide important information of the earlier development of the weakness zones.

\section{Deep structure and depth extent of $P G$ faults}

The PG faults with fault scarps longer than about $50 \mathrm{~km}$ are very probably related to deep structures of crustal depth scale (Arvidsson 1996). We could postulate that shorter faults would represent shallower structures. This could be investigated with high resolution microseismic networks and drilling in the uppermost $5-10 \mathrm{~km}$ of crust. Most of the Fennoscandian postglacial faults are thrusts with dip angles of about $30-60^{\circ}$ at the surface (Munier \& Fenton 2004). Shallow drilling $(<500 \mathrm{~m})$ has usually confirmed these observations (Bäckblom \& Stanfors 1989; Olesen et al. 1992; Roberts et al. 1997; Kuivamäki et al. 1998). Reflection seismic sounding of the Pärvie PG fault (Juhlin et al. 2009) suggested that the structure comprises several faults. The main fault $(150 \mathrm{~km}$ long $)$ dips to the east at about $50^{\circ}$ and can be continued to about $2 \mathrm{~km}$ depth. There are two (maybe three) shorter additional faults which dip steeply $75^{\circ}$ to $\mathrm{E}$ but also $60^{\circ}$ to $\mathrm{W}$. As a whole the faults may form a flower structure joining to a major fault at $10-20 \mathrm{~km}$ depth. The Pärvie faults cannot be followed to depths greater than about $5-6 \mathrm{~km}$ with the seismic reflection data. On the other hand, the first results from a recent seismic survey done for mineral exploration in central Lapland, Finland, but accidentally crossing the Suosselkä PG fault, suggest that the fault structure possibly can be followed to $4-5 \mathrm{~km}$ depth at a dip of $40-50^{\circ} \mathrm{SE}$ (Kukkonen et al. 2009b).

\section{Textural, mineralogical and physical alteration of fault rocks}

In all PG faults investigated in detail the faulting has produced distinct deformation and fracturing of the host rock. In the Stuoragurra PG fault (Figs. 4 and 5), a total of three percussion drill holes and one core drilling down to a depth of 135 metres are located along a profile perpendicular to the Stuoragurra postglacial fault (Olesen et al. 1992; Roberts et al. 1997; Dehls et al. 1999b). The drill holes revealed that the postglacial fault at shallow depth has a dip of c. $40^{\circ}$ to the SE and consists of several thin (a few $\mathrm{cm}$ thick) zones of clay minerals within a $1.5 \mathrm{~m}$ thick interval of fractured quartzite (Olesen et al. 1992; Roberts et al. 1997). The clay zones consist of kaolinite, vermiculite, smectite, goethite and chlorite and represent most likely a weathered fault gouge (Åm 1994). Several $2-3 \mathrm{~m}$ thick zones of lithified breccia within a 25 wide interval reveal that the postglacial fault occurs within an old zone of weakness partly coinciding with the margins of deformed Paleoproterozoic albite diabases. Magnetic modeling of the albite diabase in the vicinity of the drill holes shows a dip of c. $40^{\circ}$ to the SE (Olesen et al. 1992) consistent with the results from the drilling. Resistivity and refraction seismic profiling show both low resistivity $(900 \mathrm{ohmm})$ and seismic velocity $(3800 \mathrm{~m} / \mathrm{s})$ and indicate a high degree of fracturing.

In the Pasmajärvi fault, there is an old brecciated fault zone in the granitic host rock. The reactivated PG fault zone is $15-20 \mathrm{~m}$ thick as revealed by trenching and shallow diamond drilling (two holes, the deepest extending down to about $70 \mathrm{~m}$ below surface, Fig. 6). Fracture density is high (up to 60 fractures $/ \mathrm{m}$ ) and there is a clay gouge, about $1 \mathrm{~m}$ thick at the lower contact

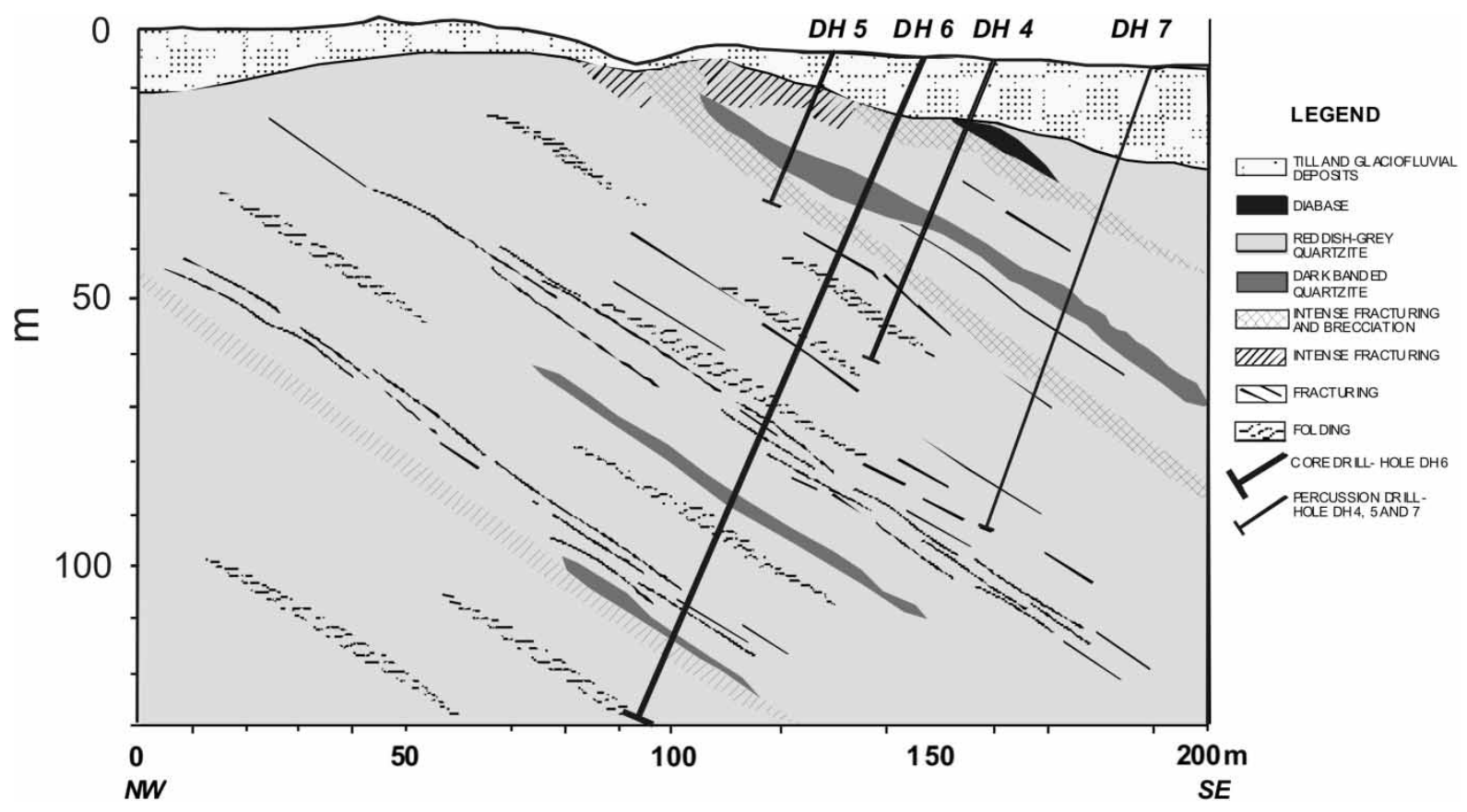

Fig. 5. Interpretation profile across the Stuoragurra Fault based on core (DH6) and percussion (DH4 and 5) drilling and geophysical measurements (Olesen et al. 1992; Roberts et al. 1997). 


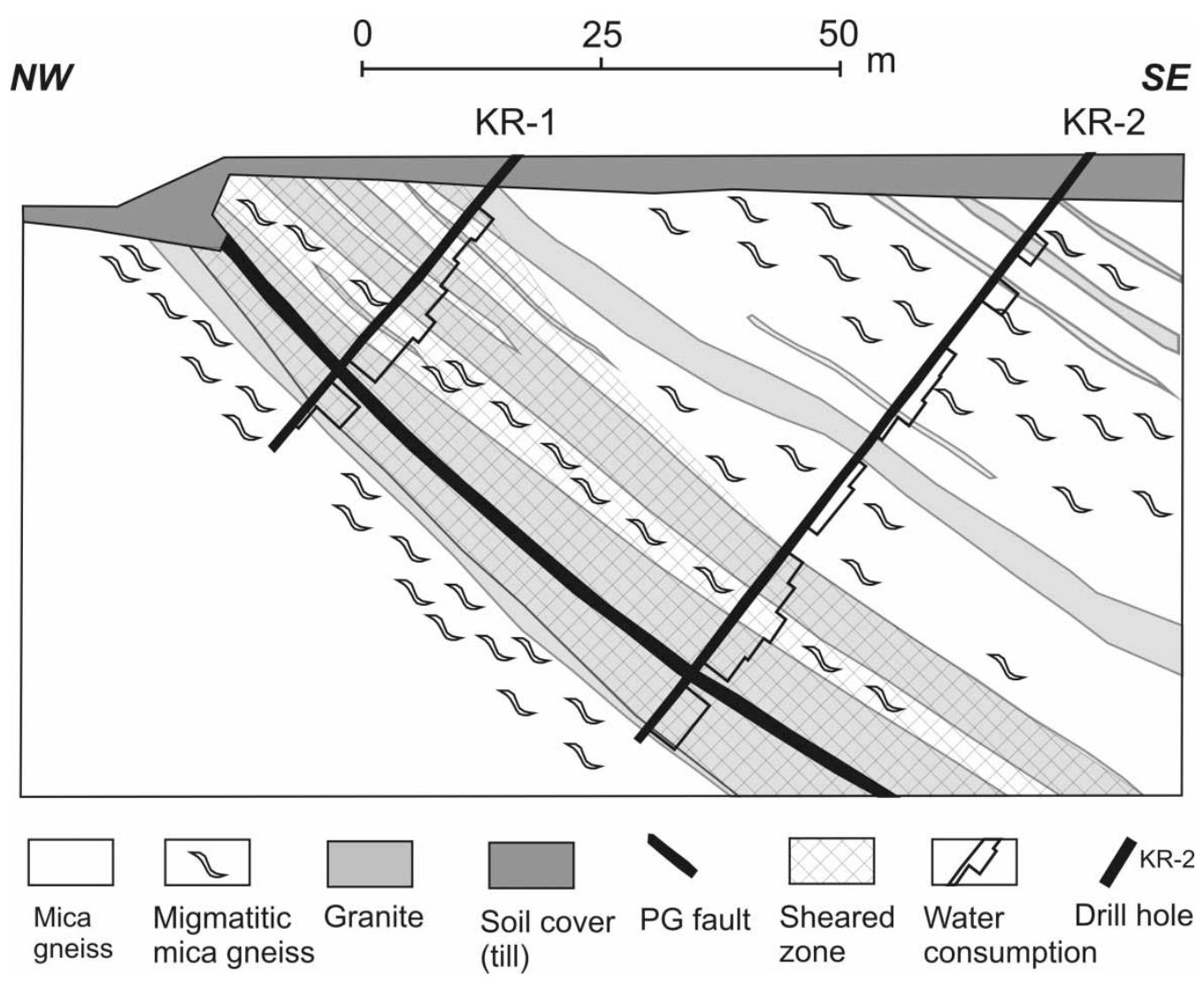

Fig. 6. Cross section of the surface part of the Pasmajärvi PG fault, Finland (see Fig. 1 for location) based on shallow diamond drilling and excavation results (redrawn from Kuivamäki et al. 1998). The highest values of water consumption corresponds to a hydraulic conductivity of about $1 \cdot 10^{-5} \mathrm{~m} / \mathrm{s}$.

of the fracture zone. The breccia is apparently very old, and has recrystallized several times (Kuivamäki et al. 1998). Unfortunately, no detailed mineralogical studies or dating of the Pasmajärvi fracture minerals, fault gouge or breccia have been conducted so far.

In an extensive study of the Lansjärv fault (Bäckblom \& Stanfors 1989; Bjarnason et al. 1989) a $500 \mathrm{~m}$ deep hole was drilled from the hanging wall side of the PG fault. The hole intersected fractured granite with minor amphibolite and pegmatite veins. Fracturing was high in the uppermost $300 \mathrm{~m}$, and the PG fault was mainly represented by intensive fracturing in an about $100 \mathrm{~m}$ thick zone. Mineralogical and geochemical studies of the fracture filling minerals indicated extensive hydrothermal alteration in oxidizing conditions, and subsequently a less extensive low temperature mobilization of $\mathrm{U}$ and REE and dissolution of calcite (Landström et al. 1989).

\section{Hydrogeology, hydrochemistry and hydraulic properties of $P G$ faults}

Hydraulic testing has been carried out in the Lansjärv and Pasmajärvi PG faults. In Lansjärv, hydraulic packer tests were carried out in 3-30 m test intervals in the $500 \mathrm{~m}$ deep hole (Larsson 1989). Relatively high hydraulic conductivity $\left(10^{-6}\right.$ $10^{-5} \mathrm{~m} / \mathrm{s}$ ) was found in the uppermost $200 \mathrm{~m}$ (approximately at where the high fracturing by the PG fault is located), whereas values of $10^{-10}-10^{-7} \mathrm{~m} / \mathrm{s}$ dominated at depths beneath and a generally decreasing trend of conductivity with depth was recorded. In Pasmajärvi, water consumption tests in two shallow drill holes indicated a high hydraulic conductivity $\left(10^{-7}-10^{-5}\right.$ $\mathrm{m} / \mathrm{s}$ ) in the shear zone (Kuivamäki et al. 1998). In the Stuoragurra PG fault, test pumping of drillhole No. 7 (Fig. 5) revealed a groundwater yield of $16.8 \mathrm{~m}^{3} /$ hour which is among the highest ever recorded in Norway (Olesen et al. 2004). The measured yield was the maximum pumping capacity of the applied pump. All these observations imply that PG faults, at least in the uppermost bedrock, are likely associated with increased hydraulic conductivity.

The paleohydrology of the PG faults is mostly an unstudied subject. One can speculate that glacial melt waters would have penetrated to the deep bedrock along the fault. How deep it is likely to have reached cannot be estimated with present data. A first approximation of this depth could be obtained from determining the depth where the compositionally fresh meteoric ground water changes into a saline fluid. Saline fluids are dominant in ('normal') crystalline bedrock in Fennoscandia from depths of 500-1000 m downward (e.g. Nurmi et al. 1988). An interesting problem is related to the palaeopermafrost conditions at the fault sites. Presumably permafrost has extended to depths of several hundred meters and would have affected the hydraulic properties of the fault.

Groundwater chemistry has been studied in the Lansjärv fault (Bjarnason et al. 1989). Samples pumped from depths of 150 and $237 \mathrm{~m}$ represented dilute fresh groundwaters with low electrolyte contents. In Lansjärv the fluid was $\mathrm{Na}-\mathrm{Ca}-\mathrm{HCO}_{3}-\mathrm{Cl}$ type and quite comparable to shallow granitic bedrock fluids in general. Eh was negative and $\mathrm{pH}$ was high indicating reducing alkaline conditions. 
Chemical analysis of the groundwater from a depth of 41 metres in the Stuoragurra fault shows a pH close to neutral (7.17) (Klemetsrud \& Hilmo 1999) and rather high contents of $\mathrm{Cu}$ and $\mathrm{Zn}$ (0.019 and $0.028 \mathrm{mg} / \mathrm{l}$, respectively) indicating sulphide mineralizations in the fault or in the vicinity of the fault. A spring of water can be observed at a distance of 25 metres from the fault scarp (Olesen et al. 1992). The spring causes a $25 \mathrm{~m}$ long and $3-5 \mathrm{~m}$ wide zone with no other vegetation than the flower Viscaria Alpina and some moss. This is due to naturally coppercontaminated groundwater. Chemical analysis of three soil samples from this zone show copper contents of $0.36,0.50$ and $1.34 \%$ (Olesen et al. 1992). The groundwater in the drillhole also had an anomalously high $\mathrm{CO}_{2}$ content of $20-40 \mathrm{mg} / \mathrm{l}$ while the median for Norwegian groundwater is $10-15 \mathrm{mg} / \mathrm{l}$.

\section{Contemporary and past stress states}

The only direct stress measurements of PG faults to our knowledge have been carried out in the Lansjärv fault using hydraulic fracturing (Bäckblom \& Stanfors 1989; Bjarnason et al. 1989). The results revealed an anomalous stress pattern with extremely low minimum stress magnitudes, with the orientation of the maximum horizontal stress rotating about $90^{\circ}$ between NW-SE and ENE-WSW. The results were attributed to tectonic disturbances by Bjarnason et al. (1989).

Knowledge of the paleostress requires data on the contemporary stress field and numerical analyses of the temporal evolution of the stress field. Detailed characterization of the current stress field and its stress sources is required. These data are then applied in numerical analyses of how the stress field is influenced by different ice load weights and configurations. Theoretical modeling of the bedrock stress field under a glacial load has been carried out by several authors (e.g., Johnston 1989; Wu \& Hasegawa 1996a, 1996b; Johnston et al. 1998; Klemann \& Wolf 1998; Wu et al. 1999; Lund 2005; Turpeinen et al. 2008; Lund et al. 2009). These studies have indicated that earthquake activity is diminished under an ice sheet but greatly enhanced at the end of deglaciation. The size of the ice sheet and its temporal evolution affects the amplification of the maximum horizontal stress, and areas glaciated by small ice sheets tend to be more sensitive for fault instability. The mode of failure depends on the spatial and temporal location under the ice load, and thrust faulting is expected to occur at the end of the glaciation and normal faulting in the regions outside the ice for the postglacial times. The initial state of stress is very important for the fault instability. These factors are further influenced, although not dominated, by the fault friction, thickness of the elastic lithosphere and the rheological properties of the asthenosphere. Lateral variations in thickness of the elastic lithosphere, e.g. at the continental margin, can induce significant variations in fault instability. Modelling results are, however, quite dispersive. For example, depending on the selection of time for isostatic equilibrium, either before the onset of glaciations ( $\mathrm{Wu}$ et al. 1999) or at glacial maximum (Stein et al. 1989), quite contradictory modes of faulting have been modelled (Bungum et al. in press).

\section{Seismicity}

PG faults in northern Sweden are considered to be products of single events which took place at the end of Weichselian glaciation (Lagerbäck \& Sundh 2008). If PG faults show any present activity, it can be studied with either passive seismic monitoring or geodetic observations on the surface or strain measurements in drill holes. The present seismic activity in Fennoscandia shows only a weak correlation with the postglacial rebound (Fig. 2; Ahjos \& Uski 1992; Wu et al. 1999), however, the earthquake epicenter locations do correlate with PG faults in northern Sweden (Arvidsson 1996). Many earthquakes are located on the eastern (downdip) side of the PG faults and the deepest earthquakes have their foci as deep as $34-37 \mathrm{~km}$ (Arvidsson 1996). This evidence suggests that the PG faults are still seismically active and relevant structures in the crustal scale.

Geodetic leveling and GPS measurements of the Pasmajärvi PG fault, Finland, and a regional lineament constraining the fault (Poutanen \& Ollikainen 1995; Kuivamäki et al. 1998) did not show any measurable bedrock movement over a monitoring period of about ten years. Either there is no movement at all, or the movement is below the detection limit in the time frame monitored. The result does not necessarily indicate a complete stagnation of the fault, particularly as some earthquakes are located close to the Pasmajärvi area (Kuivamäki et al. 1998). On the other hand, geological trenching of the faults in Sweden suggests that the sediments on the fault scrap stabilized very quickly after faulting and have been stable without any detectable movement thereafter (Lagerbäck \& Sundh 2008).

Liquefaction of sediments and landslides are spatially associated with many of the postglacial fault lines, indicating the seismogenic origin of the faults (Kuivamäki et al. 1998; Munier \& Fenton 2004; Sutinen 2005; Lagerbäck \& Sundh 2008). The Lansjärv fault is partly below the highest shoreline of the Baltic, and if formed by an earthquake magnitude $\mathrm{M}_{\mathrm{W}} \approx 7.8$ (Arvidsson 1996) it could well have generated tsunamis in principle. However, the relatively shallow water depth of the Baltic Ice Lake has probably moderated the effects.

Disturbed sedimentary structures (slides, slumps, debris flows, turbidite-type structures and pockmarks) in the Gulf of Bothnia neighboring the Olkiluoto waste disposal site were interpreted as indications of palaeoseismic activity with an age of about 10,650-10,200 cal. yr BP (Kotilainen \& Hutri 2004; Hutri \& Kotilainen, 2007; Hutri 2007; Hutri et al. 2007), which is a few hundred years after the deglaciation of the area.

\section{The deep biosphere in $P G$ faults}

So far no data is available on deep biosphere of PG faults, and new research is needed to open this question. Generally, the existence of microbial communities in the deep crystalline bedrock has been verified in several studies (e.g., Pedersen 2000; Chivian et al. 2008). Although, the present and ancient biogeochemical processes in the Precambrian crystalline bedrock terrains are not yet well understood, it is expected that microbes are present at depth in PG faults. One can speculate that faulting may have mixed microbial populations by opening pathways for fluid flow, and a fundamental question is whether the anticipated fresh water intrusion has transported microbes to greater depths.

\section{Scientific and societal relevance of PG fault} research

PG faulting which occurs during the deglaciation stage represents the most active time of rapid movements affecting glaciated areas, whereas glacials and interglacials represent 
more quiescent periods. Studies of PG faulting potentially contribute to understanding glacio-isostatic land uplift mechanisms, relations of plate tectonic and glacio-isostatic stresses, deep groundwater hydrology and chemistry as well as the deep biosphere in previously glaciated areas. Understanding PG faulting is relevant not only for Fennoscandia, but for all areas on Earth which have been or are currently covered with ice sheets. The present climatic warming is expected to enhance melting of ice sheets, and earthquakes may be triggered in areas experiencing deglaciation. Fennoscandia is a unique study area having a number of wide-spread PG faults in a recently deglaciated region that in general is well investigated geologically and geophysically.

PG faulting is a major component of neotectonic activity during the late-glacial and post-glacial times in northern Europe, and presumably in other previously glaciated areas as well. Past glacial periods of northern Europe have commonly had a cyclicity of 40-100 ka during the last $3 \mathrm{Ma}$ (e.g. Petit et al. 1999; Ruddiman 2001). Supposedly, PG faulting would have been equally common after all previous glaciations. However, it has been suggested (Lagerbäck \& Sundh 2008) that PG faulting is constrained only to the last deglaciation, because relatively modest glacial erosion should allow fault scarps to be preserved, if faulting had occurred. This could reflect different state of background stress during the last deglaciation than during previous glacial cycles. The plate tectonic stress field probably has not essentially varied in Fennoscandia during the Quaternary. The unloading of the Norwegian continental shelf and loading of the seaward continental slope and oceanic crust have, however, increased substantially during the last 2-3 million years. The temporal and spatial extent of glaciations have also varied (Svendsen et al. 2004), and the PG faulting of previous glaciations may have gone unrecognized. These questions cannot be finally answered with the present data.

In northern Europe, seismic activity is low to moderate, characteristic of stabilized shield areas. However, our understanding of the neotectonic and seismic activity is based on time series which extend only over a few decades (instrumental earthquake records) to a few centuries (historical earthquake data, e.g. Ahjos \& Uski 1992). Relatively little is known of the interaction of plate tectonic stresses and glacially induced stresses over time periods of thousands of years. Furthermore, glaciation, and in particular, deglaciation associated with rapid changes in ice load, may have included bedrock deformation and seismic activity on a much larger scale than that signaled by the sharp and easily identified PG faults. For instance, the esker formations, i.e., formations of sand and gravel deposited by glacial melt waters under withdrawing ice sheet, are often located on top of weak zones in bedrock. Their locations may have been controlled by bedrock response to changing ice loads under a shrinking glacier. Understanding the stress field development during the Weichselian deglaciation will help in predicting tectonic evolution and earthquake risk in areas where glaciers are melting due to the present climatic warming (Wu \& Hasegawa 1996a, 1996b; Lund 2005; Turpeinen et al. 2008).

Improved understanding of PG faulting, and of neotectonics in Fennoscandia, would illuminate the mechanisms of the land uplift in particular and earthquake mechanisms in general. Are the current relatively weak seismic activity and land uplift in Fennoscandia due only to glacio-isostatic compensation interacting with background stress, or are (pure) tectonic forces also involved, for instance, in the area of present maximum uplift (up to $9 \mathrm{~mm} / \mathrm{yr}$ ) in the Bothnian Bay area between Finland and Sweden? Numerous hydropower dams and plants in the northern parts of Scandinavia are vulnerable to active faulting and large-magnitude earthquakes. An improved understanding of present day seismicity along the PG faults will improve the earthquake risk assessment of the region.

The final disposal of spent nuclear fuel at about $500 \mathrm{~m}$ depth is planned in Finland and Sweden, and better understanding of PG faulting would be highly relevant to predicting the behavior of bedrock hosting nuclear repositories. Expert views vary on how long it will take until the next glacial period will start, mostly depending on how the early long-term anthropogenic effects starting from the Neolithic, as well as the modern greenhouse gas emissions and the astronomically controlled solar insolation variations are considered to affect the past and future climate (Boulton et al. 2001; Berger \& Loutre 2002; Ruddiman 2003; Müller \& Pross 2007). The next glacial period is expected to incept at about $10 \mathrm{kyr}$ after the present at the earliest, but within the next $50 \mathrm{kyr}$ at the latest. Therefore, the repository will be potentially subject to $\mathrm{PG}$ faulting, which may generate unfavorable conditions for the safe behavior of the repository. Investigations of the tectonic and hydraulic properties, hydrogeology and hydrochemistry, as well as the deep biosphere of PG faults, will directly contribute to the repository safety assessment; for example, by estimating possible migration conduits for radionuclides and assessing the risk of corrosion of disposal canisters.

The failure of oil exploration in the Barents Sea is mainly attributed to the young uplift and erosion of the shelf areas. The gas in the reservoirs has expanded as a result of the pressure relief and forced the oil out below the spill point of the reservoirs (Nyland et al. 1992). Pressures lower than hydrostatic have also been reported in several of the exploration wells in the Barents Sea causing loss of mud in the wells (Riis 2010). Several different mechanisms have been suggested for this phenomenon (Swarbrick \& Osborne 1998) but no consensus has been reached at the moment. High-quality stress measurements at depth across the seismically active postglacial faults may shed light on these intriguing questions that have significant bearings when estimating the remaining petroleum reserves on the LofotenBarents Sea margin.

Postglacial faults in the Central Lapland Greenstone belt in Finland are located in areas of economic mineral exploration. Some PG faults are located in areas of gold exploration and mining, and are related to gold-bearing structures (Kukkonen et al. 2009b). The known Precambrian orogenic hydrothermal deposits in the area date back to ca. $1.9 \mathrm{Ga}$ and are always controlled by tectonic structures. Thus, research on PG faults is also capable of contributing to our understanding of economic and mineral resources and their processes of formation. In addition, knowledge about whether the PG faults are active or not in north Sweden and Norway may provide important input for assessing hazards of large hydropower dams in this region.

\section{Motivation for drilling studies}

Many different disciplines and approaches can be used to improve our understanding of PG faults. One of them is certainly earthquake seismology together with stress field modelling and surface monitoring of any present fault activity. But here 
we want to underline the potential and importance of direct sampling of PG faults at depth and in situ investigations of these structures, i.e. studies using drilling.

Comprehensive studies on PG faulting have been carried out in Finland, Sweden and Norway utilizing structural/tectonic investigations, ground and airborne geophysical surveys, earthquake seismology, reflection seismic studies, excavations and even shallow drilling (Figs. 2-6). Furthermore, some old exploration drill cores have been noted to accidentally intersect known PG faults (e.g. Kuivamäki et al. 1998). The shallow drill cores have shown the importance of direct in situ information from bedrock, as the fault lines are in most cases covered with Quaternary deposits preventing direct sampling of the fault at the surface. While shallow excavations provide essential information on Quaternary stratigraphy, surface weathering often makes it difficult to estimate the fault properties at depth, and excavations may reach only a few metres' depth at maximum in sediments. At the moment, systematic in situ information at depth is lacking on PG faults.

Drilling is important for obtaining samples, providing downhole monitoring and measurements, calibration of geophysical models, etc. Drilling with coring is the only means to obtain undisturbed samples at depth for detailed petrographical and geochemical studies of the various deformation products along the fault zones and for age determinations of the host rock and fracture fillings of PG faults. Drill cores are obligatory for petrophysical and rock mechanic laboratory studies. Furthermore, deep biosphere studies require uncontaminated core and fluid samples, which cannot be recovered without drilling.

Without drilling it would be impossible to carry out hydrogeological studies in situ for determination of hydraulic properties of PG faults, or to do deep fluid sampling. Downhole logging of drill holes as well as VSP (vertical seismic profiling) studies are also important components of in situ studies of PG faults and provide necessary correlation with surface geophysical data.

In situ stress measurements and long-term observation of relevant parameters in drill holes (e.g. long-term seismicity and pore pressure) are a key for understanding the present stress field and activity, if any, of PG faults.

Therefore, in situ information and deep core samples are crucial for addressing many questions related to PG faults. In our view, the history, structure and present activity of PG faults can only be solved by combining shallow and deep drilling with active and passive seismic studies and geodetic surface and subsurface (strain measurement) monitoring of the PG fault structures. Alteration, deep biosphere studies, and hydrogeology and contemporary stress state studies can only be solved with drilling, i.e., using drill core samples, in situ experiments and in situ sampling of fluid in drill holes.

We expect that multidisciplinary research projects applying shallow and deep drilling of postglacial faults would provide significant scientific results through generating new data and models, namely:

1. Understanding PG fault genesis and controls of their locations;

2. Deep structure and depth extent of PG faults;

3. Textural, mineralogical and physical alteration of rocks in the PG faults;

4. State of stress and estimates of paleostress of PG faults;
5. Hydrogeology, hydrochemistry and hydraulic properties of PG faults;

6. Dating of tectonic reactivation(s) and temporal evolution of tectonic systems hosting PG faults;

7. Existence/non-existence of deep biosphere in PG faults;

8. Data useful for planning radioactive waste disposal in crystalline bedrock;

9. Data on rock stress changes in the periphery of the inland ice;

10. Stress pattern along the Norwegian continental margin in relation to the bending spreading ridge and PlioPleistocene erosion, uplift and sedimentation with implications for fluid migration and sealing properties of petroleum reservoirs.

11. Data useful in predicting future seismic activity in areas of current deglaciation due to ongoing climatic warming.

\section{Conclusions}

We consider the postglacial faults in Fennoscandia to have great potential as targets for scientific drilling projects. We suggest investigating, via scientific drilling, the tectonic and structural characteristics of postglacial faults in northern Fennoscandia, their present and past seismic activity and state of stress, as well as their hydrogeology and associated deep biosphere. Scientific advances in neotectonics, hydrogeology and deep biosphere studies are expected. Societal benefits include generating information relevant to nuclear waste disposal and exploration of petroleum and mineral deposits.

Acknowledgements. - We want to thank two anonymous referees for their constructive comments.

\section{References}

Adams, J., 1989: Postglacial faulting in eastern Canada: nature, origin and seismic hazard implications. Tectonophysics 163, 323-331.

Ahjos, T. \& Uski, M., 1992: Earthquakes in northern Europe 1375-1989. Tectonophysics 203, 1-23.

Arvidsson, R., 1996: Fennoscandian earthquakes: Whole crustal rupturing related to postglacial rebound. Science 274, 744-746.

Åm, M., 1994: Mineralogisk og petrologisk karakterisering av vitrings/sleppemateriale fra Stuoragurraforkastningen, Finnmark. Norwegian University of Science and Technology Project Report, $102 \mathrm{pp}$.

Bäckblom, G. \& Stanfors, R. (eds.), 1989: Interdisciplinary study of post-glacial faulting in the Lansjärv area, northern Sweden, 1986-1988. Swedish Nuclear Fuel and Waste Management Co., Stockholm, Technical Report 89-31.

Berger, A. \& Loutre, M.F., 2002: An exceptionally long interglacial ahead? Science 297, 1287-1288.

Bjarnason, B., Zellman, O. \& Wikberg, B., 1989: Drilling and borehole description. In G. Bäckblom \& R. Stanfors (eds.): Interdisciplinary study of post-glacial faulting in the Lansjärv area, northern Sweden, 1986-1988, 7:17:14. Swedish Nuclear Fuel and Waste Management Co., Stockholm, Technical Report 89-31.

Boulton, G.S., Kautsky, U., Morén, L. \& Wallroth, T., 2001: Impact of long-term climate change on a deep geological repository for spent nuclear fuel. Swedish Nuclear Fuel and Waste Management Co., Stockholm, Technical Report 99-05. $117 \mathrm{pp}$.

Bungum, H. \& Lindholm, C., 1997: Seismo- and neotectonics in Finnmark, Kola Peninsula and the southern Barents Sea. Part 2: Seismological analysis and seismotectonics. Tectonophysics 270, 15-28.

Bungum, H., Olesen, O., Pascal, C., Gibbons, S., Lindholm, C., Atakan, K. \& Vestøl, O., in press: To what extent is the present seismicity of Norway driven by postglacial rebound? Journal of the Geological Society of London.

Byrkjeland, U., Bungum, H. \& Eldholm, O., 2000: Seismotectonics of the Norwegian continental margin. Journal of Geophysical Research 105, $6221-6236$.

Cavanagh, A.J., Di Primio, R., Scheck-Wenderoth \& Horsfield, B., 2006: Severity and timing of Cenozoic exhumation in the southwestern Barents Sea. Journal of the Geological Society of London 163, 761-774.

Chivian, D., Brodie, E.L., Alm, E.J., Culley, D.E., Dehal, P.S., DeSantis, T.Z., Gihring, T.M., Lapidus, A., Lin, L.-H., Lowry, S.R., Moser, D.P., Richardson, 
P.M., Southam, G., Wanger, G., Pratt, L.M., Andersen, G.L., Hazen, T.C., Brockman, F.J., Arkin, A.P. \& Onstott, T.C., 2008: Environmental genomics reveals a single-species ecosystem deep within Earth. Science 322, 275-278

Dehls, J., Olesen, O., Olsen, L. \& Blikra, L.H., 2000a: Neotectonic faulting in northern Norway; the Stuoragurra and Nordmannvikdalen postglacial faults. Quaternary Science Reviews 19, 1445-1460.

Dehls, J., Olesen, O., Blikra, L.H. \& Olsen, L., 2000b: Neotectonic excursion guide to Finnmark and Troms. Norges geologiske undersøkelse, Report 99.082, 34 pp.

Hutri, K.-L., 2007: An approach to palaeoseismicity in the Olkiluoto (sea) area during the early Holocene. Radiation and Nuclear Safety Authority (STUK), Finland. Report STUK-A222. 64 pp.

Hutri, K.-L. \& Kotilainen, A., 2007: An acoustic view into Holocene palaeoseismicity offshore southwestern Finland, Baltic Sea. Marine Geology 238, 45-59.

Hutri, K.-L., Heinsalu, A., Kotilainen, A.T. \& Ojala, A.E.K., 2007: Dating early Holocene palaeoseismic event(s) in the Gulf of Bothnia, Baltic Sea. Boreas $36,56-64$.

Johnston, A., 1989: The effect of large ice sheets on earthquake genesis. In S. Gregersen \& P. Basham (eds.): Earthquakes at North-Atlantic passive margins: Neotectonics and postglacial rebound, 581-599. Kluwer Academic Publishers, Dordrecht.

Johnston, P., Wu, P. \& Lambeck, K., 1998: Dependence of horizontal stress magnitude on load dimension in glacial rebound models. Geophysical Journal International 132, 41-60.

Juhlin, C., Dehghaaejad, M., Lund, B., Malehmir, A. \& Pratt, G., 2009: Reflection seismic imaging of the end-glacial Pärvie fault system, northern Sweden. Journal of Applied Geophysics, doi:10.1016/j.jappgeo.2009.06.004.

Klemann, V. \& Wolf, D., 1998: Modelling of stresses in the Fennoscandian lithosphere induced by Pleistocene glaciations. Tectonophysics 294, 291-303.

Klemetsrud, T. \& Hilmo, B.O., 1999: Groundwater studies in the Stuoragurra fault. In J. Dehls \& O. Olesen (eds.): Neotectonics in Norway, 143-145. Annual technical report 1998. Norges geologiske undersøkelse Report 99.007.

Kotilainen, A. \& Hutri, K.-L., 2004: Submarine Holocene sedimentary disturbances in the Olkiluoto area of the Gulf of Bothnia, Baltic Sea: a case of postglacial seismicity. Quaternary Science Reviews 23, 1125-1135.

Kuivamäki, A., Vuorela, P. \& Paananen, M., 1998: Indications of postglacial and recent bedrock movements in Finland and Russian Karelia. Geological Survey of Finland, Nuclear Waste Disposal Research, Report YST-99. 92 pp.

Kujansuu, R., 1992: The deglaciation of Finnish Lapland. In L.K. Kauranne (ed.): Glacial stratigraphy, engineering geology and earth construction. Geological Survey of Finland, Special Paper 15, 21-31.

Kukkonen, I.T., Olesen, O., Ask, M. \& PFDP Working Group, 2009a: Postglacial Fault Drilling Project (PFDP). Workshop proposal to the International Continental Scientific Drilling Program, Jan. 15, 2009, 13 p.

Kukkonen, I., Lahti, I., Heikkinen, P., Heinonen, S., Laitinen, J. \& HIRE Working Group of the Geological Survey of Finland, 2009b: HIRE Seismic Reflection Survey in the Suurikuusikko gold mining and exploration area North Finland. Geological Survey of Finland, Report Q 23/2009/28, 51 pp.

Lagerbäck, R., 1979: Neotectonic structures in northern Sweden. Geologiska Föreningens i Stockholm Förhandlingar 100, 263-269.

Lagerbäck, R., 1990: Late Quaternary faulting and paleoseismicity in northern Fennoscandia, with particular reference to the Lansjärv area, northern Sweden. Geologiska Föreningens $i$ Stockholm Förhandlingar 112, 333-354

Lagerbäck, R. \& Sundh, M., 2008: Early Holocene faulting and paleoseismicity in northern Sweden. Sveriges geologiska undersökning C836, 80 pp

Landström, O., Smellie, J. \& Tullborg, E.-L., 1989: Mineralogical and geochemical studies of fracture-infillings in drillcore KLJ 01. In G. Bäckblom \& R. Stanfors (eds.): Interdisciplinary study of post-glacial faulting in the Lansjärv area, northern Sweden, 1986-1988, 9:1-9:17. Swedish Nuclear Fuel and Waste Management Co., Stockholm, Technical Report 89-31.

Larsson, N.-A., 1989: Hydrogeological conditions. In G. Bäckblom \& R. Stanfors (eds.): Interdisciplinary study of post-glacial faulting in the Lansjäry area, northern Sweden, 1986-1988, 8:1-8:13. Swedish Nuclear Fuel and Waste Management Co., Stockholm, Technical Report 89-31.

Lukashov, A.D., 1995: Paleoseismotectonics in the northern part of Lake Onega (Zaonezhkij Peninsula, Russian Karelia). Geological Survey of Finland, Nuclear Waste Disposal Research, Report YST-90. 36 pp.

Lund, B., 2005: Effects of deglaciation on the crustal stress field and implications for endglacial faulting: A parametric study of simple Earth and ice models. Swedish Nuclear Fuel and Waste Management Co., Stockholm. Technical Report TR-05-04. 68 pp

Lund, B., Schmidt, P. \& Hieronymus, C., 2009: Stress evolution and fault instability during the Weichselian glacial cycle. Swedish Nuclear Fuel and Waste Management Co., Stockholm. Technical Report TR-09-15. 106 pp.

Lundqvist, J., 1994: Inlandisens avsmältning. In C. Freden (ed.): Berg och jord, Sveriges Nationalatlas, 124-135. Stockholm, Sveriges National Atlas Förlag.

Muir Wood, R., 1989: Extraordinary deglaciation reverse faulting in northern Fennoscandia. In S. Gregersen \& P.W. Basham (eds.): Earthquakes at NorthAtlantic passive margins: neotectonics and postglacial rebound, 141-173. Kluwer Academic Publishers, Dordrecht, The Netherlands.

Muir Wood, R., 1993: A review of the seismotectonics of Sweden. Swedish Nuclear Fuel and Waste Management Co. Technical Report 93-13, 225 pp.
Muir Wood, R., 2000: Deglaciation seismotectonics: a principal influence on intraplate seismogenesis at high latitudes. Quaternary Science Reviews 19 $1399-1411$

Munier, R. \& Fenton, C., 2004: Current understanding and directions for future studies. In R. Munier \& H. Hökmark (eds.): Respect distances: Rationale and means of computation, 157-218. Swedish Nuclear Fuel and Waste Management Co., Stockholm, Report R-04-17.

Müller, U.C. \& Pross, J., 2007: Lesson from the past: present insolation minimum holds potential for glacial inception. Quaternary Science Reviews 26, 3025-3029.

Nurmi, P., Kukkonen, I. \& Lahermo, P., 1988: Geochemistry and origin of saline groundwaters in the Fennoscandian Shield. Applied Geochemistry 3, 185-203.

Nyland, B., Jensen, L.N., Skagen, J., Skarpnes, O. \& Vorren, T., 1992: Tertiary uplift and erosion in the Barents Sea: magnitude, timing and consequences. In R.M. Larsen, H. Brekke, B.T. Larsen \& E. Talleraas (eds.): Structural and tectonic modelling and its application to petroleum geology, 153-162. Norwegian Petroleum Society Special Publications 1, Elsevier, Amsterdam.

Ojala, V.J., Kuivamäki, A. \& Vuorela, P., 2004: Postglacial deformation of bedrock in Finland. Geological Survey of Finland, Nuclear Waste Disposal Research, Report YST-120. 23 pp.

Olesen, O., 1988: The Stuoragurra Fault, evidence of neotectonics in the Precambrian of Finnmark, northern Norway. Norsk Geologisk. Tidsskrift 68 , $107-118$.

Olesen, O., Henkel, H., Lile, O.B., Mauring, E. \& Rønning, J.S., 1992: Geophysical investigations of the Stuoragurra postglacial fault, Finnmark, northern Norway. Journal of Applied Geophysics 29, 95-118.

Olesen, O., Blikra, L.H., Braathen, A., Dehls, J.F., Olsen, L., Rise, L., Roberts, D., Riis, F., Faleide, J.I. \& Anda, E., 2004: Neotectonic deformation in Norway and its implications: a review. Norwegian Journal of Geology 84, $3-34$.

Olesen, O., Bungum, H., Dehls, J., Lindholm, C., Pascal, C. \& Roberts, D., in press: Neotectonics, seismicity and contemporary stress field in Norway mechanisms and implications. In D. Roberts, Ø. Nordgulen \& L. Olsen (eds.) Geology of Norway. Norges geologiske undersøkelse Special Publications.

Pascal, C. \& Cloetingh, S.A.P.L., 2009: Gravitational potential stresses and stress field of passive continental margins: Insights from the south-Norway shelf. Earth and Planetary Science Letters 277, 464-473.

Pedersen, K., 2000: Exploration of deep intraterrestrial microbial life: current perspectives. Federation of European Microbiological Societies Microbiology Letters 185, 9-16.

Petit, J.R., Jouzel, J., Raynaud, D., Barkov, N.I., Barnola, J.-M., Basile, I., Bender, M., Chappellaz, J., Davis, M., Delaygue, G., Delmotte, M Kotlyakov, V.M., Lipenkov, V., Lorius, C., Pepin, L., Ritz, C., Saltzman, E. \& Stievenard, M., 1999: Climate and Atmospheric History of the Last 420,000 Years from the Vostok Ice Core, Antarctica. Nature 399, 429.

Poutanen, M. \& Ollikainen, M., 1995: GPS measurements at the Nuottavaara postglacial fault. Finnish Geodetic Institute, Report $95.6 \mathrm{pp}$

Riis, F., 1996: Quantification of Cenozoic vertical movements of Scandinavia by correlation of morphological surfaces with offshore data. Global and Planetary Change 12, 331-357.

Riis, F., 2010: Erosion and pore pressure reduction in the south-western Barents Sea. Abstract at the 29th Nordic Geological Wintermeeting, Oslo, January 11-13, 2010, Abstracts and Proceedings of the Geological Society of Norway 1,161 .

Roberts, D., Olesen, O. \& Karpuz, M.R., 1997: Seismo- and neotectonics in Finnmark, Kola Peninsula and the southern Barents Sea. Part I: Geological and neotectonic framework. Tectonophysics 270, 1-13.

Ruddiman, W.F., 2001: Earth's climate, past and future. W.H. Freeman and Company, New York. 465 pp.

Ruddiman, W., 2003: The Anthropogenic Greenhouse Era began thousands of years ago. Climate Change 61, 261-293.

Sollid, J.L., Andersen, S., Hamre, N., Kjeldsen, O., Salvigsen, O., Sturød, S., Tveitå, T. \& Wilhelmsen, A., 1973: Deglaciation of Finnmark, North Norway. Norsk Geografisk Tidsskrift 27, 233-325.

Stein, S., Cloetingh, S., Sleep, N.H. \& Wortel, R., 1989: Passive margin earthquakes, stresses and rheology. In S. Gregersen \& P.W. Basham (eds.): Earthquakes at North-Atlantic Passive Margins; Neotectonics and Postglacial Rebound, 231-259. NATO ASI Series, Series C: Mathematical and Physical Sciences 266, D. Reidel Publishing Company. Dordrecht-Boston, International.

Sutinen, R., 2005: Timing of early Holocene landslides in Kittilä, Finnish Lapland. In A.E.K. Ojala (ed.): Quaternary studies in the northern and Arctic regions of Finland, Proceedings of the workshop organized within the Finnish National Committee for Quaternary Research (INQUA), Kilpisjärvi Biological Station, Finland, January 13-14th 2005. Geological Survey of Finland, Special Paper 40, 53-58.

Svendsen, J.I., Alexanderson, H., Astakhov, V.I., Demidov, I., Dowdeswell, J.A., Funder, S., Gataullin, V., Henriksen, M., Hjort, C., Houmark-Nielsen, M. Hubbertenk, H-W., Ingolfsson, O., Jakobsson, M., Kjær, K.H., Larsen, E., Lokrantz, H., Lunkka, J.P., Lyså, A., Mangerud, J., Matiouchkov, A., Murray, A., Möller, P., Niessen, F., Nikolskaya, O., Polyak, L., Saarnisto, M., Siegert, C., Siegert, M.J., Spielhagen, R.F. \& Stein, R., 2004: Late Quaternary ice sheet history of northern Eurasia. Quaternary Science Reviews 23, 1229-1271.

Swarbrick, R.E. \& Osborne, M.J., 1998: Mechanisms that generate abnormal pressures: an overview. In B.B. Law, G.F. Ulmishek \& V.I. Slavin (eds.): 
Abnormal pressures in hydrocarbon environments. American Assosiation of Petroleum Geologists Memoir 70, 13-34.

Turpeinen, H., Hampel, A., Karow, T. \& Maniatis, G., 2008: Effect of ice sheet growth and melting on the slip evolution of thrust faults. Earth and Planetary Science Letters 269, 230-241.

Vestøl, O., 2006: Determination of postglacial land uplift in Fennoscandia from leveling, tide-gauges and continuous GPS stations using least squares collocation. Journal of Geodesy 80, 248-258.

\section{Appendix}

Postglacial Fault Drilling Project Working Group

Principal investigators:

Ilmo T. Kukkonen, Geological Survey of Finland, Espoo, Finland Odleiv Olesen, Geological Survey of Norway, Trondheim, Norway Maria V.S. Ask, Luleå University of Technology, Luleå, Sweden

Working Group members:

Lasse Ahonen, Geological Survey of Finland, Finland Daniel Ask, Vattenfall Power Consultant, Sweden Andrea Hampel, Ruhr-Universität Bochum, Germany Ralf Hetzel, Westfälische Wilhelms-Universität Münster, Germany Merja Itävaara, Technical Research Centre of Finland, Finland Christopher Juhlin, University of Uppsala, Sweden Oddbjørn Kløvjan, Statoil, Norway Aimo Kuivamäki, Geological Survey of Finland, Finland Juha-Pekka Lunkka, University of Oulu, Finland Birgit Müller, Karlsruhe University, Germany Øystein Nordgulen, Geological Survey of Norway, Norway Christophe Pascal, Geological Survey of Norway, Norway Victoria Pease, Stockholm University, Sweden

Markku Poutanen, Geodetic Institute, Finland, Finland Jan Steinar Rønning, Geological Survey of Norway, Norway Hans-George Scherneck, Chalmers University of Technology, Sweden Liisa Wikström, Posiva Oy, Finland, Finland
Wu, P. \& Hasegawa, H.S., 1996a: Induced stress and fault potential in eastern Canada due to a disc load: a preliminary analysis. Geophysical Journal International 125, 415-430.

Wu, P. \& Hasegawa, H.S., 1996b: Induced stresses and fault potential in eastern Canada due to a realistic load: a preliminary analysis. Geophysical Journal International 127, 215-229.

Wu, P., Johnston, P. \& Lambeck, K., 1999: Postgalcial rebound and fault instability in Fennoscandia. Geophysical Journal International 139, 657-670. 